\title{
RANCANG BANGUN SISTEM KONTROL DEBIT AIR PADA POMPA PARALEL BERBASIS ARDUINO
}

\author{
Edo Saputra \\ Fakultas Teknik, Program Studi Teknik Mesin \\ Universitas Muria Kudus \\ Email :edo54putra@gmail.com \\ Masruki Kabib \\ Fakultas Teknik, Program Studi Teknik Mesin \\ Universitas Muria Kudus \\ Email :masruki.kabib@umk.ac.id \\ Bachtiar Satya Nugraha \\ Fakultas Teknik, Program Studi Teknik Mesin \\ UniversitasMuria Kudus \\ Email :bachtiar.setya@umk.ac.id
}

\begin{abstract}
ABSTRAK
Pompa merupakan alat yang digunakan untuk memindahkan fluida atau air dari bak penampung air yang satu ke bak penampung air yang lain. Sistem pompa paralel adalah sebuah sistem yang terdiri dari beberapa unit pompa, sistem perpipaan dan panel kontrol yang dihubungkan untuk dapat menghasilkan kapasitas air yang lebih besar selain itu bisa sebagai pompa cadangan ketika pompa yang satu sedang rusak atau pompa dalam proses perbaikan. Perancangan sistem kontrol debit air pada pompa paralel bertujuan mengontrol debit air pada pompa yang disusun paralel dengan daya pompa berbeda. Menggunakan daya pompa 75Watt, 125Watt, dan 200Watt dengan sensor flow meter untuk membaca debit air yang diolah menggunakan mikrokontroler arduino atmega 2560. Hasil pengendalian debit maksimal 15 liter/menit dan pengendalian debit maksimal 80 liter/menit, data penyimpangan pengendalian debit 0,9 liter/menit.
\end{abstract}

Kata Kunci : debit aliran, pompal paralel, sistem kontrol.

\begin{abstract}
The pump is a tool used to move fluid or water from a reservoir of water to another container. Parallel pumping system is a system consisting of several pump units, piping systems and control panels that are connected to be able to produce a larger water capacity other than that it can be a backup pump when one pump is damaged or the pump is in the process of repair. The design of a water discharge control system at a parallel pump aims to control the water discharge in a pump that is arranged parallel with different pump power. Using 75Watt, 125Watt, and 200Watt pump power with a flow meter sensor to read the water discharge that is processed using an Arduino Atmega 2560 microcontroller. Maximum discharge control results of 15 liters / minute and maximum discharge control of 80 liters / minute, debit control deviation data of 0.9 liters / minute.
\end{abstract}

Keywords: flow discharge, parallel pumping, control system. 


\section{PENDAHULUAN}

Perkembangan teknologi yang semakin pesat telah membawa banyak pengaruh dalam berbagai aspek kehidupan. Dahulu orang bekerja secara manual dengan bantuan alat sederhana, selanjutnya berkembang dengan mesin dan motor sebagai penggerak peralatan, kemudian berkembang lagi menjadi otomasi, mesin atau motor dipadukan dengan sistem elektronik digital.

Pompa merupakan sebuah mesin fluida yang dapat digunakan untuk mengalirkan fluida dari permukaan yang lebih rendah ketempat yang lebih tinggi, ataupun dari tempat yang lebih tinggi ketempat yang lebih rendah. Pompa digunakan untuk memindahkan fluida dengan memberikan kerja mekanis melalui sudu-sudu atau baling baling. Fluida tersebut contohnya adalah air, oli atau minyak pelumas, atau fluida lainnya yang memiliki sifat tak mampu dimampatkan. Pompa juga dipakai pada motor bakar yaitu sebagai pompa pelumas, bensin atau air pendingin. 1 debit air pada pompa paralel menggunakan sensor water flow meter, alat untuk mengukur aliran sebuah fluida pada luas suatu penampang tertentu [1] .

Pompa paralel adalah beberapa unit pompa yang dihubungan pada saluran pipa yang sama yang dipasang secara paralel. Pada suatu pompa yang dipasang secara paralel akan menghasilkan kapasitas air yang lebih besar dengan kapasitas air yang kelipatanya dari setiap pompa yang terpasang dengan catatan bahwa pompa yang dipasang secara paralel mempunyai kapasitas pompa yang sama [2].

Perancangan sistem pompa paralel adalah untuk mendapatkan peningkatan kapasitas air dengan menggunakan variasi daya pompa. Metode yang digunakan dimulai dengan study literature, analisa kebutuhan alat, pembuatan desain, perancangan dan perhitungan rangka, kapasitas air [3].

Sistem kendali adalah alat untuk mengendalikan, memerintah, dan mengatur keadaan suatu sistem, sistem kontrol meningkatkan dapat meningkatkan kapasitas produksi dan mempermudah pengoprasian. perancangan sistem pengendalian debit aliran masukan suatu tandon air untuk mengatur ketinggian level cairan. Perancangan dilakukan dengan menggunakan mikrokontroler Atmega 8535 sebagai pusat kendali, sensor PING untuk sensor ketinggian level cairan [4].

Rangkaian pengontrol tegangan AC sebagai suplay tegangan pada pompa air untuk mengatur debit aliran air. Merancangan sistem informasi perhitungan debit air berbasis Arduino UNO. Debit dan volum air yang melalui sensor dapat dipantau dari jarak jauh melalui web browser. Prototipe yang akan dirancang dan perangkat monitor akan terhubung melalui jaringan komputer [5].

Sensor water flow meter berfungsi untuk menghitung debit air yang mengalir yang memutar rotor dalam satuan Liter. Sensor ini terdiri dari beberapa bagian antara lain katup plastik, rotor air, dan sensor hall efek. Rotor akan berputar serta kecepatan akan berubah-ubah sesuai dengan kecepatan aliran air yang mengalir. Pada sensor hall efek yang terdapat pada sensor ini akan membaca sinyal tegangan yang berupa pulsa dan mengirim sinyal tersebut ke mikrokontroler dalam hal ini arduino dan diolah sebagai data laju akan debit air yang mengalir.

Sistem kontrol debit air pada pompa paralel untuk mengatur debit aliran air berdasarkan kapasitas yang dimasukan. Upaya yang dapat dilakukan untuk mengatasi masalah pada mesin tersebut adalah dengan merancang suatu sistem kontrol pompa agar kapasitas yang dikeluarkan sesuai dengan kapasitas yang dimasukan.

\section{METODOLOGI PENELITIAN}

Metodologi penelitian ini dimulai dari studi literature, analisa kebutuhan sistem kontrol, sistem pompa paralel.

Langkah - langkah perancangan dilakukan sebagai berikut :

1. Melakukan studi literature untuk mendapatkan informasi dari jurnal tentang perancangan sistem kontrol dan perancangan sebelumnya yang telah dilakukan. 
2. Melakukan analisa terhadap kebutuhan sistem kontrol yang digunakan untuk dapat menentukan rangkaian sistem kontrol yang sesuai.

3. Melakukan proses perancangan sistem kontrol yang meliputi analisa sistem pompa paralel, Diagram blok sistem kontrol, Sistem kontrol arduino, Komponen yang digunakan.

4. Melakukan perancangan dan pembuatan rangkaian hardware sistem kontrol. Komponen untuk diperancangan hardware : mikrokontroler arduino ATMEGA2560, sensor debit air, keypad, LCD, relay, power supply, pompa sentrifugal daya 75 Watt, 125 Watt, dan 200 Watt.

5. Melakukan pembuatan software yaitu pemograman control menggunakan software CodevisionAVR.

6. Melakukan pengujian sistem kontrol debit air pada pompa paralel.

\section{HASIL DAN PEMBAHASAN}

\subsection{Analisa Debit Air Pompa Paralel}

Pompa yang dipasang secara paralel sebagaimana ditunjukkan pada gambar 1 maka kapasitas pompa parallel dapat dihitung berdasarkan persamaan 1 :

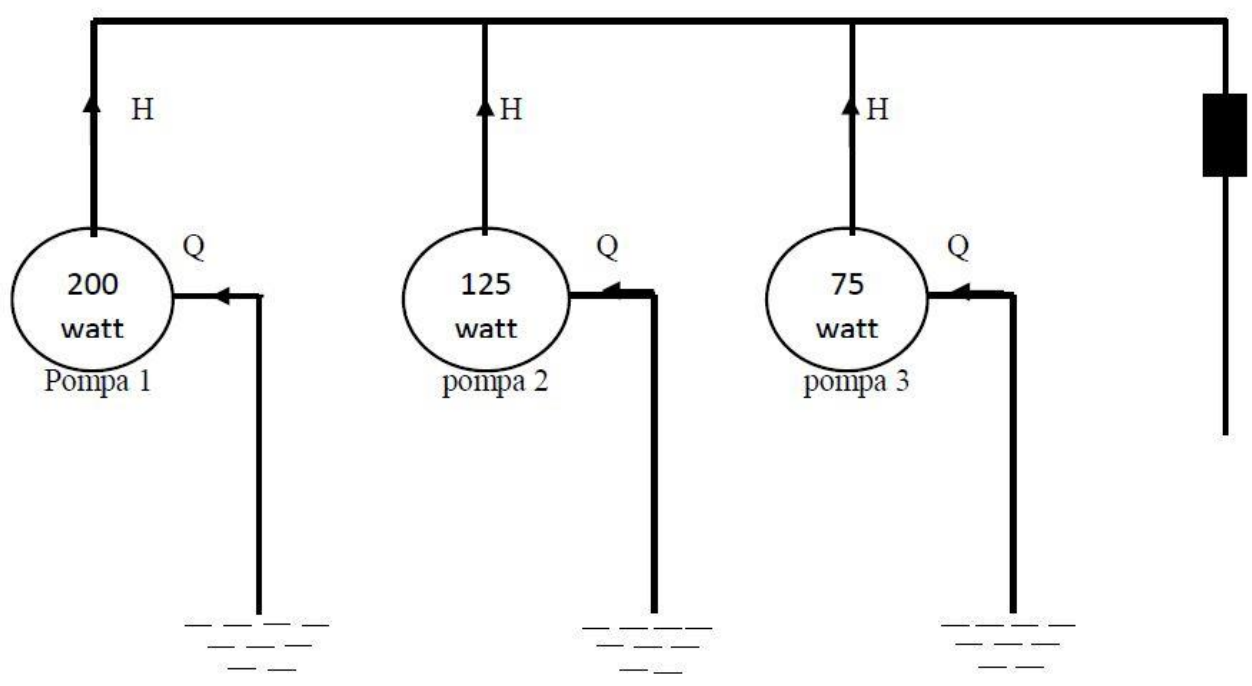

Gambar 1.Sketsa sistem pompa paralel

$Q_{\text {total pompa parelel }}=Q_{1}+Q_{2}+Q_{3}$

Hasil perhitungan system pompa parallel sebagaimana di tunjukkan pada table 1 : 
Tabel 1 Hasil perhitungan kapasitas air

\begin{tabular}{|c|c|c|}
\hline Perhitungan & Persamaan & Hasil \\
\hline Pompa 1 & (1) & $15 \mathrm{~L} /$ menit \\
\hline Pompa 2 & (1) & $25 \mathrm{~L} /$ menit \\
\hline Pompa 3 & (1) & $40 \mathrm{~L} /$ menit \\
\hline Pompa all & (2) & $80 \mathrm{~L} /$ menit \\
\hline
\end{tabular}

\subsection{Diagram blok sistem}

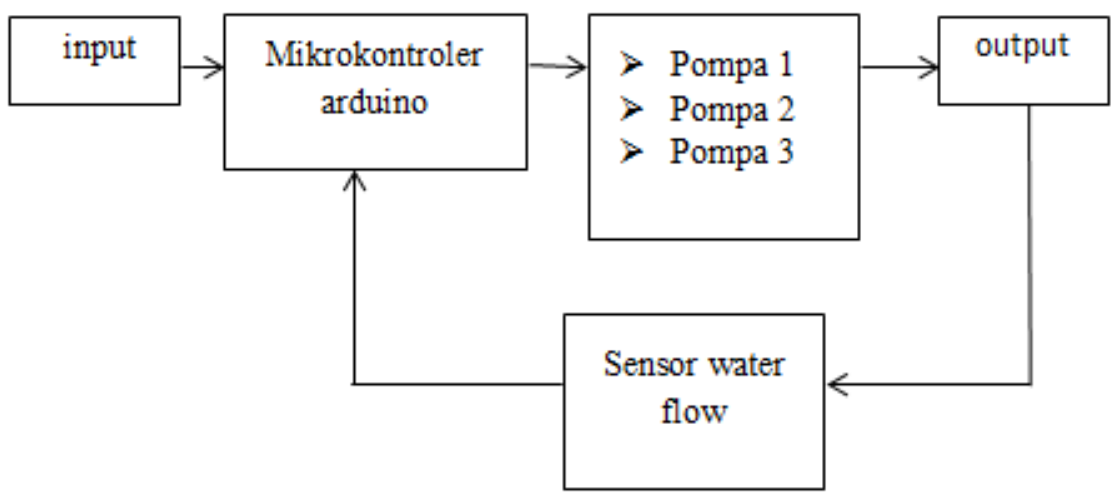

Gambar 2. Diagram blok sistem kontrol pompa paralel

Gambar 2 menunjukkan diagram blok pompa parallel. Blok input adalah bagian yang memberi perintah kapasitas yang dimasukan, input kapasitas dimasukan melalui keypad. Blok arduino Atmega 2560 untuk mengolah data dari input kapasitas dari keypad dan sensor debit air menyesuaikan kapasitas yang dimasukan. Blok LCD untuk menampilkan input kapasitas dari keypad dan pembacaan sensor debit air oleh arduino. Blok pompa untuk menghasilkan debit air. Blok sensor debit air untuk membaca debit air yang dihasilkan oleh pompa yang disusun secara paralel.

\subsection{Hardware}




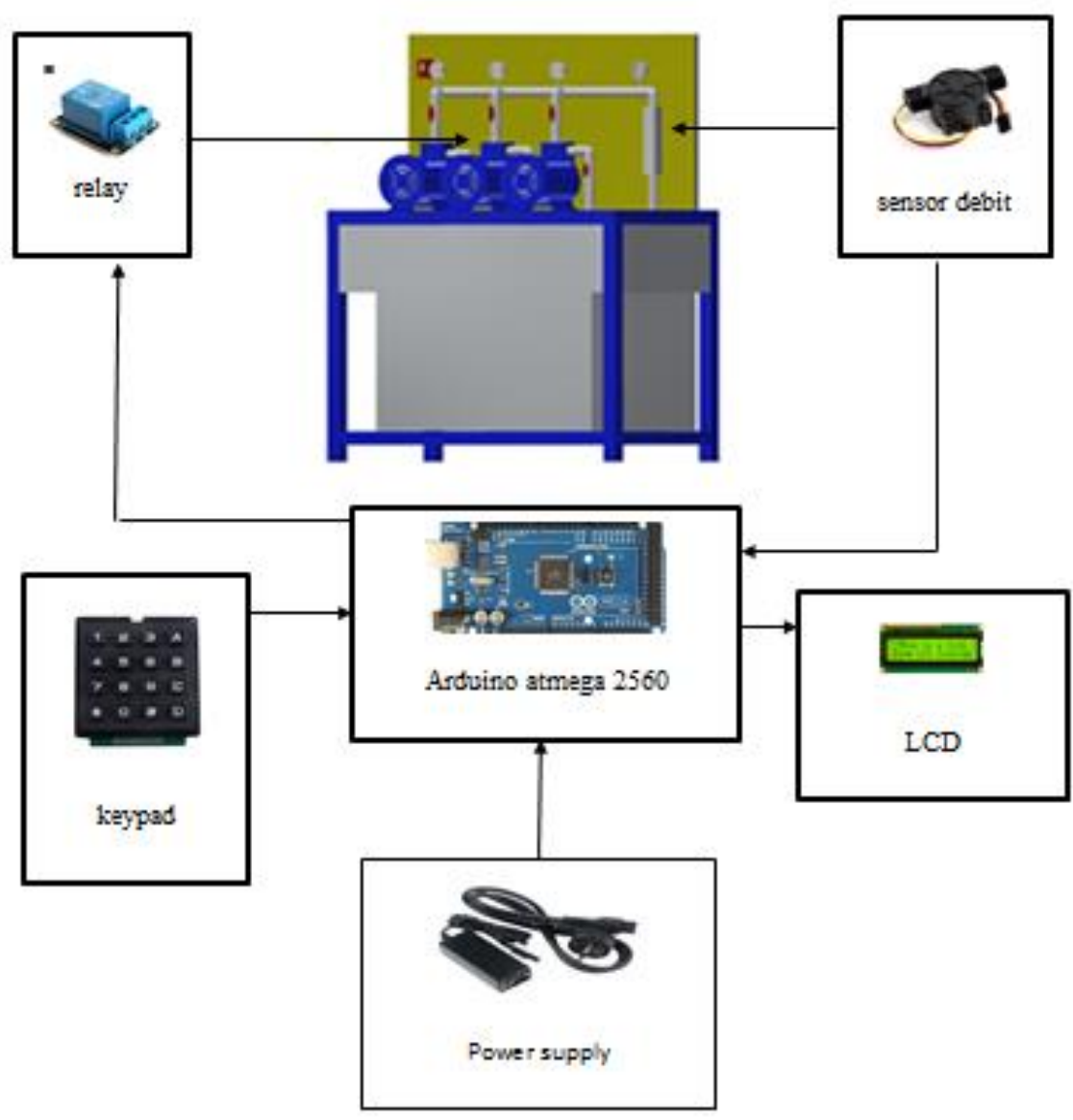

Gambar 3. Hardware sistem control pompa paralel

Rangkaian hardware system kontrol debit air pada pompa parallel ditunjukkan pada gambar 3. Yang terdiri atas arduino atmega 2560 sebagai mikrokontroler, LCD untuk menampilkan data, sensor debit untuk membaca debit aliran, dan relay untuk mengontrol nyala pompa.

\subsubsection{LCD}

LCD yang digunakan adalah 16x2 karakter yang akan digunakan untuk menampilkan nilai debit yang diinginkan melalui keypad dan menampilkan nilai debit yang dihasilkan oleh pompa. Proses penampilan data ini dilakukan dengan instruksi "lcd_gotoxy $(0,1)$ " instruksi ini akan mengarahkan kursor ke baris diinginkan dan instruksi "ftoa(nilai,0,buff)" akan mengkonversi nilai debit yang dihasilkan dari keypad menjadi karakter yang akan dimasukkan ke buffer LCD. Instruksi "lcd_puts(buff)" diunakan untuk mengirim karakter hasil dari nilai debit yang ada dibuffer ke LCD.

\subsubsection{Keypad}

Keypad digunakan untuk memasukkan data nilai debit yang dinginkan dan untuk menyalakan motor. Dengan sistem scanning arduino akan membaca PORTF.4 sampai PORTF.7 
dan ketika tombol ditekan mikro akan merespon sinyal yang dihasilkan kemudian Arduino akan menampilkanya ke LCD dan mengkonversi nilai ke variable debit yang dibutuhkan. Keypad ini juga berfungsi sebagai tombol start untuk motor yaitu pada karakter $(*)$. Ketika tombol ini ditekan Arduino akan mengeksekusi perintah menyalakan motor dengan perhitungan yang sesuai dengan nilai debit yang dimasukkan.

\subsubsection{Sensor Debit}

Sensor debit yang digunakan adalah dengan tipe rotary dengan aliran maksimal yang bisa diukur adalah $250 \mathrm{l} / \mathrm{m}$. Cara pengukuranya dengan menghitung hall sensor yang nilainya sebanding dengan nilai debit aliran air. Sensor dihubungkan ke bagian eksternal interupsi Arduino, jika terjadi putaran maka arduino akan mendetekasi dan menghitung nilai debit dengan dara membaca jarak waktu antara trigger pertama dan trigger ke $\mathrm{x}$, dengan waktu didapatkan dari timer internal dari Arduino dan nilai x dapatkan dari banyaknya interupsi dari sensor yang dihasilkan .

Dimana nilai konstanta dihasilkan dengan membandingkan nilai debit yang didapakan dari sensor debit yang sudah terkalibrasi.

Dari nilai flow yang didapatkan maka akan dikurangkan dengan nilai debit yang dimasukkan uintuk mendapatkan nilai Error. Nilai error ini digunakan untuk mendapatkan nilai PID dan nilai PID akan menghasilkan nilai $P W M$ yang digunakan untuk membuat delay ON/OFF untuk mengontrol relay agar mendapatkan nilai aliran atau debit yang akurat.

\subsubsection{Relay dan Motor}

Relay ini berfungsi sebagai saklar otomatis untuk menyalakan relay. Arduino akan mengolah nilai debit yang dimasukkan untuk menyalakan relay. Karena ada 3 relay untuk menyalakan motor dengan nilai debit dari 10 liter/menit sampai 80 liter/menit.

Relay 1 menyalakan pompa dengan debit maksimal 15 1/m

Relay 2 menyalakan pomba dengan debit maksimal $25 \mathrm{l} / \mathrm{m}$

Relay 3 menyalakan pompa dengan debit maksimal 40 1/m

Logika pengendalian debit pada pompa paralel sebagai berikut:

1. Ketika nilai debit yang dimasukkan berada di 15 maka hanya relay 1 yang bekerja dengan mode on/off untuk mendapatkan nilai debit yang akurat

2. Ketika nilai debit yang dimasukkan sama dengan 15 maka relay 1 akan menyala terus karena nilai maksimalnya sama dengan debit yang dimasukkan

3. Ketika nilai debit yang dimasukkan berada diatas 15 dan dibawah 25 relay 2 akan bekerja dengan mode on/off untuk mendapatkan nilai debit yang akurat

4. Ketika nilai debit yang dimasukkan sama dengan 25 maka relay 2 akan menyala terus karena nilai maksimalnya sama dengan debit yang dimasukkan

5. Ketika nilai debit yang dimasukkan berada diatas 25 dan dibawah 40 relay 1 akan menyala terus dan relay 2 akan bekerja dengan mode on/off untuk mendapatkan nilai debit yang akurat

6. Ketika nilai debit yang dimasukkan sama dengan 40 maka relay 1 dan relay 2 akan menyala terus karena nilai maksimalnya sama dengan debit yang dimasukkan

7. Ketika nilai debit yang dimasukkan berada diatas 40 dan dibawah 55 relay 3 akan menyala terus dengan nilai debit maksimal 40 dan relay 1 akan bekerja dengan mode on/off untuk mendapatkan nilai debit yang akurat

8. Ketika nilai debit yang dimasukkan sama dengan 55 maka relay 1 dan relay 3 akan menyala terus karena nilai maksimalnya sama dengan debit yang dimasukkan

9. Ketika nilai debit yang dimasukkan berada diatas 55 dan dibawah 65 relay 3 akan menyala terus dengan nilai debit maksimal 40 dan relay 2 akan bekerja dengan mode on/off untuk mendapatkan nilai debit yang akurat 
10. Ketika nilai debit yang dimasukkan sama dengan 65 maka relay 2 dan relay 3 akan menyala terus karena nilai maksimalnya sama dengan debit yang dimasukkan

11. Ketika nilai debit yang dimasukkan berada diatas 65 dan dibawah 80 relay 3 dan relay 2 akan menyala terus dengan nilai debit maksimal 65 dan relay 1 akan bekerja dengan mode on/off untuk mendapatkan nilai debit yang akurat

12. Ketika nilai debit yang dimasukkan sama dengan 80 maka relay 1, relay 2 dan relay 3 akan menyala terus karena nilai maksimalnya sama dengan debit yang dimasukkan

\section{PENGUJIAN DAN HASIL}

Pada pengujian seluruh sistem dapat dilakukan dengan memasukan input debit pada kaypad sesuai yang diinginkan dengan debit minimal 15 liter/menit sampai 80 liter/menit. Data penyimpangan yang dari pengendalian Tekan karakter \# untuk mengedit angka yang akan dimasukan, setelah sudah memasukan angka tekan karakter * untuk memulai progam dan untuk menghentikan semua progam. Data hasil pengujian di tunjukkan tabel 2.

Tabel 2.Hasil Pengujian

\begin{tabular}{ccc}
\hline No. & Debit in & Debit out \\
\hline 1. & 15 liter/menit & 15,52 liter/menit \\
\hline 2. & 25 liter/menit & 26,25 liter/menit \\
\hline 3. & 30 liter/menit & 30,39 liter/menit \\
\hline 4. & 40 liter/menit & 41,40 liter/menit \\
\hline 5. & 50 liter/menit & 50,75 liter/menit \\
\hline 6. & 60 liter/menit & 59,44 liter/menit \\
\hline 8. & 70 liter/menit & 68,51 liter/menit \\
\hline 9. & 80 liter/menit & 77,57 liter/menit \\
\hline
\end{tabular}

Hasil pengujian menunjukkan bahwa debit keluaran belum bisa tepat dengan debit masukan, dengan batas debit masukan minimal 15 liter/menit dan batas maksimal 80 liter/menit

\section{KESIMPULAN}

Berdasarkan pengujian sistem kontrol debit air pada pompa paralel yang menggunakan mikrokontroller arduino atmega 2560 dapat dibuat kesimpulan pengendalian debit paling kecil yang dapat dilakukan adalah 15 liter/menit dan pengendalian debit paling besar adalah 80 liter/menit.

\section{DAFTAR PUSTAKA}

[1] Mastur, Warso, 2015. Pengaruh Putaran Terhadap Pompa Sentrifugal Pada Rangkaian Seri Dan Paralel, prosiding Senatek fakultas teknik, Universitas Muhammadiyah Purwokerto, 28 November 2015, ISBN 978-602-14355-0-2

[2] ArifAzhari, Soeharwinto, 2015, Merancangan system informasi perhitungan debit air berbasisArduino UNO.

[3] Ifan Febrianto, M Kabib, BS Nugraha. '2018, Peracancangan Sistem Pompa Paralel Dengan Daya Bervariasi Untuk Meningkatkan Kapasitas Air, Jurnal Crankshaft 1 (1), 49-54.

[4] Wahyudi, Bakhtiar Indra K, Iwan Setiawan, 2008, Merancangan sistem pengendalian debit aliran masukan suatu tandon air untuk mengatur ketinggian level cairan. Perancangan dilakukan dengan menggunakan mikrokontroler Atmega 8535. 
Jurnal CRANKSHAFT, Vol. 2 No.1. Maret 2019

ISSN: 2623-0720 (Print), 2623-0755 (Online)

[5] Suwardana, I.W, I Ketut TA, dan I Gde Wahyu, A.K. 2013, Perencanaan kontrol start otomatis pompa hydrant di politeknik negeri bali. Bali: JURNAL LOGIC. VOL. 13. NO. 2. JULI 2013 